\title{
Detection of recent climate change using daily temperature extremes in Khorasan Province, Iran
}

\author{
Sara Sanjani, Mohammad Bannayan*, Mohsen Kamyabnejad \\ Faculty of Agriculture, Ferdowsi University of Mashhad, PO Box 91775-1163, Mashhad, Iran
}

\begin{abstract}
Climate change is considered one of the main environmental concerns of the 21st century. Increased variation and changes in mean temperature and precipitation are expected to dominate future changes in climate and affect crop productivity. It is highly important to identify regions vulnerable to climate change and to identify suitable adaptation practices that can sustain productivity to some extent. In the present study, an iterative $\chi^{2}$ method was applied to detect recent possible climate change in extreme daily minimum and maximum temperatures for 5 different regions (Birjand, Boujnord, Mashhad, Sabzevar and Torbat Heydarieh) in Khorasan Province, Iran, during a recent $15 \mathrm{yr}$ period and a prior $30 \mathrm{yr}$ period. The method determines the values of extreme daily temperature that are most significantly different between the prior and recent periods and gives a measure of the weekly significance of that difference. We determined the percentage change in the frequency of the number of extreme days for each period of continuous significant weeks. In all 5 regions, a few days of extreme low minimum temperature (especially in Mashhad and Sabzevar) were experienced during the recent period. The major changes in climate for minimum temperature were determined in Mashhad. In this region the highest percentage change of climate (min. temperature) occurred during Week 33, when a $41 \%$ decrease of extreme low minimum temperatures occurred. In Mashhad the highest warming (decrease in days of min. temperature) occurred during late March to late December. Among 5 regions during the recent period some weeks experienced a greater number of days of extreme high maximum temperature (except Torbat Heydarieh and Birjand). In Torbat Heydarieh, the highest percentage change occurred during Week 24 , when a $26 \%$ decrease of extreme high maximum temperatures was detected. In Torbat Heydarieh, the highest cooling occurred from April to early December.
\end{abstract}

KEY WORDS: Global climate change $\cdot$ Daily minimum and maximum temperature $\cdot$ Temperature variability

Resale or republication not permitted without written consent of the publisher

\section{INTRODUCTION}

Global climate variability and change caused by natural processes and human activities are major and important issues that are affecting the world at the beginning of the 21st century. A warming trend has been well documented at most locations around the world during the last several decades, and this trend is projected to accelerate in the future (Tao et al. 2006). The IPCC 4th assessment report stated that the global average surface temperature has increased by $0.74 \pm 0.18^{\circ} \mathrm{C}$ in the last century and is projected to increase by another 1.1 to $6.4{ }^{\circ} \mathrm{C}$ in this century (IPCC 2007). Any change in climate will have implications for climate-sensitive systems such as agriculture (Reidsma et al. 2010, Sissoko et al. 2010), forestry (Lindner et al. 2010), and other natural resources (Southworth et al. 2000), and therefore the world's food supply (Barnet 2010).

The increasing variation and change in mean temperature and precipitation are expected to dominate future changes in climate, which will subsequently affect crop productivity (Bannayan et al. 2010). Various studies dealing with the effects of climatic vari- 
ability have pointed to the conclusion that increased annual variability of weather, as expected due to global warming, causes increased variation of yields (Porter \& Semenov 2005, Laux et al. 2010, Bannayan et al. 2011). Developing countries are more vulnerable to climate change than developed countries because of the predominance of agriculture in their economies, the scarcity of capital for adaptation measures, and their heightened exposure to extreme events (Parry et al. 2001).

There is a need to identify vulnerable district or agroclimatic regions to climate change and identify suitable adaptation practices that can, to some extent, sustain the productivity of these regions. Several studies have focused on the detection of possible climate change in Iran, especially in Khorasan Province. Kousari \& Asadi Zarch (2010) used the Mann-Kendall test to investigate trends in minimum, maximum, and mean temperature; relative humidity; and annual precipitation over the last 55 yr from 13 synoptic weather stations in Iran's arid and semi-arid regions. They found significant increasing trends for minimum and mean temperatures and a decreasing trend for mean relative humidity in the arid and semi-arid regions, especially during the last few years up to the year 2000. Ghorbani \& Soltani (2003) investigated possible climate change during the $40 \mathrm{yr}$ period 1991-2000 in the Gorgan region, located in north-central Iran. They used simple linear regression to determine the rates of change in temperature and precipitation, and showed that, while annual mean maximum and minimum temperatures had not increased, the number of days with a maximum temperature greater than $35^{\circ} \mathrm{C}$ had decreased by $0.05 \mathrm{~d} \mathrm{mo}^{-1} \mathrm{yr}^{-1}(\mathrm{p}=0.01)$ for May and $0.13 \mathrm{~d} \mathrm{mo}^{-1} \mathrm{yr}^{-1}$ for June. They concluded that there was no significant warming as a result of global environment change, but precipitation had significantly declined during past 40 yr. Ebrahimi et al. (2006) investigated recent possible climate change by comparing temperatures between a recent and a prior $25 \mathrm{yr}$ period in the Mashhad plain, located in central Khorasan. The Mann-Kendall and Lettenmaier methods were used to study the process of temperature change. They showed that there is an increasing trend in minimum and maximum temperatures. Ghahraman (2006) used a Student's $t$-test to detect trends in mean annual temperature at 34 synoptic stations in Iran with records spanning the 31 yr period 1968-1998. They found that $65 \%$ of the series showed a positive trend, $32 \%$ exhibited a negative trend, and some stations did not show any significant trend.

In the present study, an iterative $\chi^{2}$ method (Caprio et al. 2009) was used to detect recent possible climate change in extremes of daily minimum and maximum temperature at 5 regions between a recent $15 \mathrm{yr}$ (1991-2005) and a prior $30 \mathrm{yr}$ period (1961-1990). Five regions located in the Khorasan Province of Iran (Boujnord, Sabzevar, Mashhad, Torbat Heydarieh, and Birjand) were chosen due to their importance to regional agricultural production and the availability of weather data. The employed method determines which values of the extreme daily weather elements are significantly different between the prior years and the recent years, and gives a measure of the weekly significance of that difference. The procedure is also used to determine the average percentage or fraction of each day within each week of the year that is attributable to possible climate change due to extreme low daily minimum or extreme high daily maximum temperatures.

\section{METHODOLOGY}

\subsection{Study site}

The study area covers the northeast of Iran, which includes the Boujnord, Sabzevar, Mashhad, Torbat Heydarieh, and Birjand regions that are all located in Khorasan Province, Iran (Fig. 1). Physiographic details of each location are presented in Table 1. In this region, air temperature increases from northwest towards southeast. Low-temperature air originates from Siberia, which reduces the temperature starting from autumn until early spring. High-temperature air originates from the northeastern Arabian Sea.

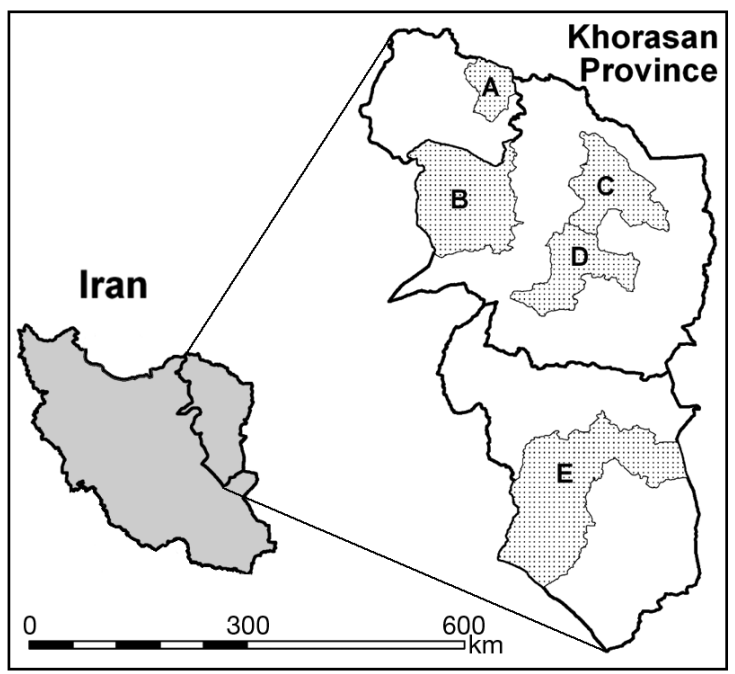

Fig. 1. Geographical study area and locations of the regions (A) Boujnord, (B) Sabzevar, (C) Mashhad, (D) Torbat Heydarieh, (E) Birjand 
Table 1. Latitude (Lat), longitude (Long), elevation (Elev), and annual average of weather variables for the study sites in Khorasan, Iran

\begin{tabular}{|lccrrrrr|}
\hline Region & Lat & Long & $\begin{array}{c}\text { Elev } \\
(\mathrm{m})\end{array}$ & $\begin{array}{c}\text { Average temperature }\left({ }^{\circ} \mathrm{C}\right) \\
\text { Min. }\end{array}$ & $\begin{array}{c}\text { Total precipitation } \\
(\mathrm{mm})\end{array}$ & Climate record \\
\hline Birjand & & & & & & \\
Boujnord & $32^{\circ} 52^{\prime} \mathrm{N}$ & $59^{\circ} 12^{\prime} \mathrm{E}$ & 1491 & 8.2 & 24.3 & 165.4 & $1961-2005$ \\
Mashhad & $37^{\circ} 28^{\prime} \mathrm{N}$ & $57^{\circ} 19^{\prime} \mathrm{E}$ & 1091 & 6.9 & 19.6 & 265 & $1977-2006$ \\
Sabzevar & $36^{\circ} 16^{\prime} \mathrm{N}$ & $59^{\circ} 38^{\prime} \mathrm{E}$ & 999 & 8.3 & 21.6 & 256.5 & $1961-2005$ \\
Torbat Heydarieh & $36^{\circ} 12^{\prime} \mathrm{N}$ & $57^{\circ} 43^{\prime} \mathrm{E}$ & 977 & 11.8 & 24.7 & 197.8 & $1961-2005$ \\
& $35^{\circ} 16^{\prime} \mathrm{N}$ & $59^{\circ} 13^{\prime} \mathrm{E}$ & 1450 & 7.5 & 20.4 & 276.6 & $1961-2005$ \\
\hline
\end{tabular}

\subsection{Weather data}

Daily weather data from 1961 to 2005 for 4 different regions (Birjand, Sabzevar, Mashhad, and Torbat Heydarieh) and from 1977 to 2006 for the 5th region (Boujnord) were obtained from meteorological stations at each region (Table 1). These stations were selected due to availability of long historical climate records. Weather data included daily minimum and maximum temperatures. The locations of the weather stations in each region remained constant during the above periods (Rahimzadeh \& Asgari 2004), and the data for each station passed homogeneity tests.

\subsection{Analysis approach}

The iterative $\chi^{2}$ method (Caprio et al. 2009) was used to detect possible recent climate changes in Sabzevar, Mashhad, Torbat Heydarieh, and Birjand between a recent $15 \mathrm{yr}$ and a prior $30 \mathrm{yr}$ period, and, in Boujnord, between a recent $10 \mathrm{yr}$ and a prior $20 \mathrm{yr}$ period. This classification of historical years is based on a few local studies that have mentioned the increasing trend of daily and monthly temperature in previous decades (Ebrahimi et al. 2006, Ghahraman 2006, Kousari \& Asadi Zarch 2010).

The iterative $\chi^{2}$ method was first developed by Caprio (1966), who examined correlations between daily weather records and annual crop yields. It has also been used to identify the critical period when weather impacts small grain and rangeland production in Montana (Caprio \& Williams 1973) and to determine the association of daily weather occurrences with apple production in British Columbia (Caprio \& Quamme 1999), horticultural crops in Ontario (McKeown et al. 2006) and canola in Saskatchewan, Canada (Kutcher et al. 2010). This technique has been subsequently used to identify percentage change in daily extremes of minimum temperature at 2 sites in northwestern North America (Caprio et al. 2009).
The analysis herein determines the possible climatic change from the early period to the recent period for both extreme minimum and extreme maximum temperatures. Initially daily minimum and maximum temperatures were sorted from low to high values for both periods. Temperatures were broken down into contiguous classes of $5^{\circ} \mathrm{C}$ across the temperature ranges for all years in all regions. The $\chi^{2}$ test was applied to each $3 \mathrm{wk}$ period and a $\chi^{2}$ value generated for each class that reported high-to-low scan for maximum temperature and low-to-high scan for minimum temperature. The $\chi^{2}$ test determines the significant difference in the frequency of days between classes and across recent and prior years. The temperature at which $\chi^{2}$ reaches its maximum point is referred to as cardinal temperature (CT). This temperature is significant at the $1 \%$ level for $\chi^{2}=7$ $(\mathrm{df}=1)$. The larger the $\chi^{2}$ value, the greater the probability that there is a real climate difference between the number of extreme days in both prior and recent years. If the recent years had excess or fewer days than expected, the $\chi^{2}$ is reported positive or negative, respectively. Excess days means that recent years have more days meeting a cardinal value than prior years and vice versa.

In order to determine average daily percentage potential climate change, we calculated the difference in the number of extreme days in the $15 \mathrm{yr}$ recent period with one half of the numbers of extreme days in the $30 \mathrm{yr}$ prior period for each overlapping $3 \mathrm{wk}$ period. Dividing the value obtained by the number of years (15) gives the difference in the number of extreme days per year. Dividing that value by the number of weeks (3) yields the difference in the number of extreme days per week. Three-week running averages of these weekly values were calculated. We then divided these weekly values of the difference in the number of extreme days per week by 7 (number of days per week), giving the average number (in fractions of a day) of extreme occurrences per day, and multiplied by 100 (Caprio et al. 2009). These daily values were plotted weekly and referred to as 
the percentage change in the occurrence of extreme daily weather conditions during the recent year due to possible climate change. According to this method, $7 \%$ was considered as the level for one-half day per week climate change (warming or cooling) and $14 \%$ as the level for one day per week climate change (warming or cooling). Further details on iterative $\chi^{2}$ analysis can be found in Caprio et al. (2003, 2009) and Caprio \& Quamme (1999, 2002, 2006).

\section{RESULTS}

\subsection{Number of days of extreme low minimum temperature}

The results for significant periods of extreme low minimum temperatures at all regions are reported in Table 2 and shown in Fig. 2. Different significant periods were reported in various regions (all dates reported as mm/dd). In Birjand there was one period during Weeks 35-38 (08/27-09/23) that had a deficit of days of extreme minimum temperature, and one period during Weeks 1-3 (01/01-01/21) that had an excess of days of extreme minimum temperature in recent years compared to prior years. During Weeks $35-38$, the maximum $\chi^{2}$ was 11 , with a CT of $\leq 5^{\circ} \mathrm{C}$ that occurred during Week 37 (09/10-09/16). The percentage of change during this week was a decrease of $6 \%$. Generally, in Birjand, the warming occurred from the end of August to mid September, as indicated by the fewer number of days of extreme low minimum temperatures.

In Boujnord, there were 2 periods in which there was a significant deficit of occurrence of extreme low minimum temperatures: Weeks 35-36 (08/20-09/02) and Weeks 39-43 (09/24-10/28) (Table 2). The maxi- mum $\chi^{2}$ of 18 occurred during Week 41 (10/08-10/14) with a CT of $\leq 10^{\circ} \mathrm{C}$. The percentage change during this week was a decrease of $16 \%$. For extreme low minimum temperature, there were 5 weeks that had at least 0.5 wk of warming and 9 weeks that had one whole week of warming. In this region the highest warming occurred from the end of September to October (Boujnord; Fig. 2c).

In Mashhad, there were deficit days of extreme minimum temperatures during all months except March and early April in recent years compared to prior years (Mashhad; Fig. 2e). Two statistically significant periods were detected during Weeks 1-8 and Weeks 17-52 (Table 2).

Fig. 2c (Mashhad) shows that the maximum $\chi^{2}$ of 76 occurred during Week $34(08 / 20-08 / 26)$ with CT of $\leq 15^{\circ} \mathrm{C}$. The highest percentage change in climate occurred during this week (08/20-08/26), when a $41 \%$ decrease of extreme minimum temperatures was detected. For extreme minimum temperature there were $15 \mathrm{wk}$ that had at least one whole week of warming. Based on the sums of all $52 \mathrm{wk}$ of extreme days, it was determined that the recent years averaged $44 \%$ fewer days of extreme low temperatures than the prior years. Generally, the highest warming occurred from May to November (Mashhad; Fig. 2c).

In Sabzevar, the deficit of occurrence of extreme low minimum temperatures was statistically significant during 2 periods (Table 2). The maximum $\chi^{2}$ of 42 occurred during Week $3(01 / 15-1 / 21)$ with CT of $\leq-5^{\circ} \mathrm{C}$. The percentage change during this week was a decrease of $19 \%$. The highest percentage change in climate was during Week 34 (08/20-08/26), when a $26 \%$ decrease in the number of days of extreme low minimum temperatures was detected. There were not a significant excess number of days of extreme low minimum temperatures (Sabzevar; Fig. 2g).

Table 2. Significant periods in the number of days of low minimum temperatures at all regions (low to high scan)

\begin{tabular}{|c|c|c|c|c|c|c|c|}
\hline Region & $\begin{array}{l}\text { Week } \\
\text { number }\end{array}$ & $\begin{array}{l}\text { Dates } \\
(\mathrm{mm} / \mathrm{dd})\end{array}$ & $\begin{array}{c}\text { Max. } \\
\text { weekly } \chi^{2}\end{array}$ & $\begin{array}{c}\text { Daily average } \\
\text { period change } \\
(\%)\end{array}$ & $\begin{array}{l}\text { Dates of } \\
\max \cdot \chi^{2} \\
\text { week }(\mathrm{s})\end{array}$ & $\begin{array}{l}\text { Daily average } \\
\text { change of max. } \\
\chi^{2} \text { week(s) }(\%)\end{array}$ & $\begin{array}{l}\text { Cardinal temp. } \\
\text { of max. } \chi^{2} \\
\text { week }(\mathrm{s})\left({ }^{\circ} \mathrm{C}\right)\end{array}$ \\
\hline Birjand & $\begin{array}{c}1-3 \\
35-38\end{array}$ & $\begin{array}{l}01 / 01-01 / 21 \\
08 / 27-09 / 23\end{array}$ & $\begin{array}{l}20 \\
11\end{array}$ & $\begin{array}{l}+4 \\
-4\end{array}$ & $\begin{array}{l}01 / 01-01 / 07 \\
09 / 10-09 / 16\end{array}$ & $\begin{array}{l}+5 \\
-6\end{array}$ & $\begin{array}{r}\leq-10 \\
\leq 5\end{array}$ \\
\hline Boujnord & $\begin{array}{l}34-35 \\
39-43\end{array}$ & $\begin{array}{l}08 / 20-09 / 02 \\
09 / 24-10 / 28\end{array}$ & $\begin{array}{r}7 \\
18\end{array}$ & $\begin{array}{r}-7 \\
-14\end{array}$ & $\begin{array}{l}08 / 27-09 / 02 \\
10 / 08-10 / 14\end{array}$ & $\begin{array}{r}-7 \\
-16\end{array}$ & $\begin{array}{l}\leq 10 \\
\leq 10\end{array}$ \\
\hline Mashhad & $\begin{array}{c}1-8 \\
17-52\end{array}$ & $\begin{array}{l}01 / 01-02 / 25 \\
04 / 23-12 / 30\end{array}$ & $\begin{array}{l}38 \\
76\end{array}$ & $\begin{array}{l}-16 \\
-21\end{array}$ & $\begin{array}{l}01 / 08-01 / 14 \\
08 / 20-08 / 26\end{array}$ & $\begin{array}{l}-24 \\
-41\end{array}$ & $\begin{array}{l}\leq-5 \\
\leq 15\end{array}$ \\
\hline Sabzevar & $\begin{array}{c}1-9 \\
26-52\end{array}$ & $\begin{array}{l}01 / 01-03 / 04 \\
06 / 25-12 / 30\end{array}$ & $\begin{array}{l}42 \\
35\end{array}$ & $\begin{array}{l}-13 \\
-15\end{array}$ & $\begin{array}{l}01 / 15-01 / 21 \\
07 / 30-08 / 05\end{array}$ & $\begin{array}{l}-19 \\
-26\end{array}$ & $\begin{array}{l}\leq-5 \\
\leq 20\end{array}$ \\
\hline Torbat Heydarieh & $\begin{array}{c}1-2 \\
50-52\end{array}$ & $\begin{array}{l}01 / 01-01 / 14 \\
12 / 10-12 / 30\end{array}$ & $\begin{array}{l}10 \\
11\end{array}$ & $\begin{array}{l}-4 \\
-4\end{array}$ & $\begin{array}{l}01 / 01-01 / 07 \\
12 / 17-12 / 23\end{array}$ & $\begin{array}{l}-4 \\
-5\end{array}$ & $\begin{array}{l}\leq-15 \\
\leq-10\end{array}$ \\
\hline
\end{tabular}



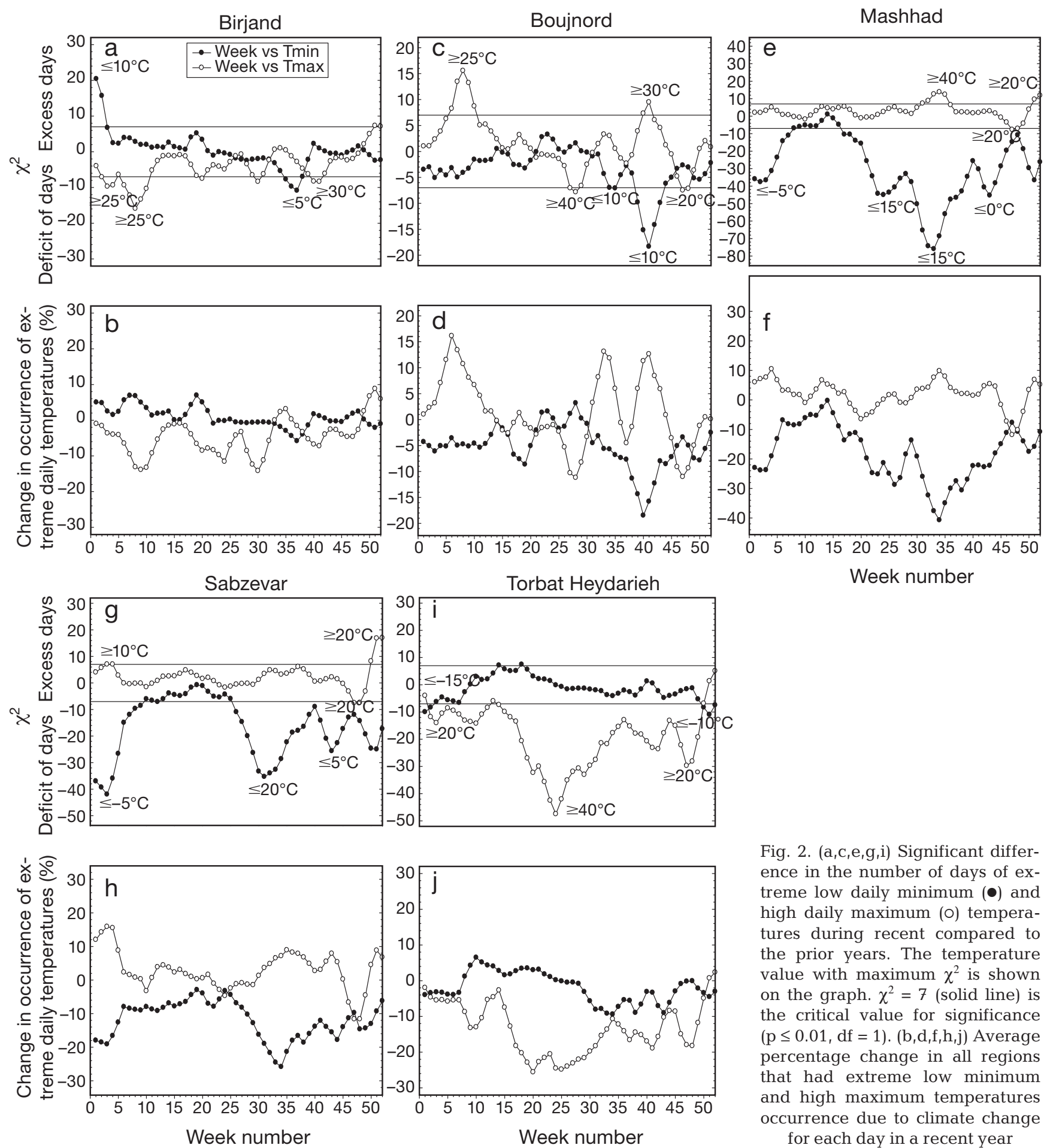

Fig. 2. (a,c,e,g,i) Significant difference in the number of days of extreme low daily minimum $(\bullet)$ and high daily maximum (o) temperatures during recent compared to the prior years. The temperature value with maximum $\chi^{2}$ is shown on the graph. $\chi^{2}=7$ (solid line) is the critical value for significance $(p \leq 0.01, d f=1) .(b, d, f, h, j)$ Average percentage change in all regions that had extreme low minimum and high maximum temperatures occurrence due to climate change for each day in a recent year

Two significant periods (01/01-03/04 and 06/2512/30) were found in which extreme daily minimum temperatures occurrence was less frequent during the recent period compared to the prior period by 34 and $52 \%$, respectively. Based on the sums of all 52 wk of extreme days, we determined that the recent years averaged $57 \%$ fewer days of extreme low temperatures than the prior years. In this region, the highest warming occurred from January to February and July to December, as indicated by the fewer number of days of extreme low minimum temperatures (Sabzevar; Fig. 2g).

In Torbat Heydarieh, 2 statistically significant periods were detected during Weeks 1-2 and Weeks 
Table 3. Significant periods in the number of days of high maximum temperatures at all regions (high to low scan)

\begin{tabular}{|c|c|c|c|c|c|c|c|}
\hline Region & $\begin{array}{c}\text { Week } \\
\text { number }\end{array}$ & $\begin{array}{c}\text { Dates } \\
(\mathrm{mm} / \mathrm{dd})\end{array}$ & $\begin{array}{c}\text { Max. } \\
\text { weekly } \chi^{2}\end{array}$ & $\begin{array}{c}\text { Daily average } \\
\text { period change } \\
(\%)\end{array}$ & $\begin{array}{l}\text { Dates of } \\
\max \cdot \chi^{2} \\
\text { week(s) }\end{array}$ & $\begin{array}{c}\text { Daily average } \\
\text { change of max. } \\
\chi^{2} \text { week(s) }(\%)\end{array}$ & $\begin{array}{l}\text { Cardinal temp. } \\
\text { of max. } \chi^{2} \\
\text { week }(\mathrm{s})\left({ }^{\circ} \mathrm{C}\right)\end{array}$ \\
\hline Birjand & $\begin{array}{c}2-4 \\
6-10 \\
40-41\end{array}$ & $\begin{array}{l}01 / 08-01 / 28 \\
02 / 05-03 / 11 \\
10 / 01-10 / 14\end{array}$ & $\begin{array}{r}10 \\
16 \\
8\end{array}$ & $\begin{array}{r}-3 \\
-11 \\
-7\end{array}$ & $\begin{array}{c}01 / 15-1 / 21 \\
02 / 19-02 / 25 \\
10 / 08-10 / 14\end{array}$ & $\begin{array}{r}-4 \\
-14 \\
-7\end{array}$ & $\begin{array}{l}\geq 25 \\
\geq 25 \\
\geq 35\end{array}$ \\
\hline Boujnord & $\begin{array}{c}6-10 \\
27-29 \\
40-41 \\
47-48\end{array}$ & $\begin{array}{l}02 / 05-03 / 11 \\
07 / 02-07 / 22 \\
10 / 01-10 / 14 \\
11 / 19-12 / 02\end{array}$ & $\begin{array}{r}16 \\
8 \\
9 \\
7\end{array}$ & $\begin{array}{l}+11 \\
-10 \\
+12 \\
-10\end{array}$ & $\begin{array}{l}02 / 19-02 / 25 \\
07 / 09-07 / 15 \\
10 / 08-10 / 14 \\
11 / 19-12 / 02\end{array}$ & $\begin{array}{l}+16 \\
-11 \\
+13 \\
-11\end{array}$ & $\begin{array}{l}\geq 25 \\
\geq 40 \\
\geq 30 \\
\geq 20\end{array}$ \\
\hline Mashhad & $\begin{array}{l}31-35 \\
47-48 \\
51-52\end{array}$ & $\begin{array}{c}7 / 30-09 / 02 \\
11 / 19-12 / 02 \\
12 / 17-12 / 30\end{array}$ & $\begin{array}{r}14 \\
8 \\
12\end{array}$ & $\begin{array}{r}+7 \\
-11 \\
+6\end{array}$ & $\begin{array}{l}08 / 20-08 / 26 \\
11 / 19-11 / 25 \\
12 / 25-12 / 30\end{array}$ & $\begin{array}{r}+10 \\
-12 \\
+7\end{array}$ & $\begin{array}{l}\geq 40 \\
\geq 20 \\
\geq 20\end{array}$ \\
\hline Sabzevar & $\begin{array}{c}3-4 \\
47-48 \\
50-52\end{array}$ & $\begin{array}{l}01 / 15-01 / 28 \\
11 / 19-12 / 02 \\
12 / 10-12 / 30\end{array}$ & $\begin{array}{r}7 \\
8 \\
17\end{array}$ & $\begin{array}{r}+16 \\
-12 \\
+7\end{array}$ & $\begin{array}{l}01 / 15-01 / 28 \\
11 / 19-11 / 25 \\
12 / 25-12 / 30\end{array}$ & $\begin{array}{r}+16 \\
-12 \\
+9\end{array}$ & $\begin{array}{l}\geq 10 \\
\geq 20 \\
\geq 20\end{array}$ \\
\hline Torbat Heydarieh & $\begin{array}{c}2-12 \\
14-49\end{array}$ & $\begin{array}{l}01 / 08-03 / 25 \\
04 / 02-12 / 09\end{array}$ & $\begin{array}{l}14 \\
48\end{array}$ & $\begin{array}{r}-7 \\
-17\end{array}$ & $\begin{array}{c}03 / 05-03 / 11 \\
06 / 11-06 / 17\end{array}$ & $\begin{array}{l}-13 \\
-26\end{array}$ & $\begin{array}{l}\geq 20 \\
\geq 40\end{array}$ \\
\hline
\end{tabular}

50-52 (Table 2). The maximum $\chi^{2}$ of 11 occurred during Week $51(12 / 17-12 / 23)$ with $\mathrm{CT}$ of $\leq-10^{\circ} \mathrm{C}$. The percentage change during this week was a decrease of $5 \%$. In Torbat Heydarieh, the greatest warming occurred in early of January and December, as indicated by the fewer number of days of extreme low minimum temperatures (Torbat Heydarieh; Fig. 2i). Generally, the major changes in climate were similar in Mashhad and Sabzevar, with greatest warming occurring throughout the whole year except spring.

\subsection{Number of days of extreme high maximum temperatures}

The results of the comparison between the number of days with extreme high maximum temperatures in prior and recent periods are shown in Table 3 and Fig. 2. In Birjand, there were 3 significant periods with fewer occurrences of extreme high maximum temperatures, which occurred during Weeks 2-4 (01/08-01/28), Weeks 6-10 (02/05-03/11), and Weeks $40-41(10 / 01-10 / 14)$. The maximum $\chi^{2}$ of 16 occurred during Week $8(02 / 19-02 / 25)$ with a CT of $\geq 25^{\circ} \mathrm{C}$. The greatest percentage change in climate occurred during Week 9 (02/26-03/04) and Week 30 (07/23$07 / 29$ ) when a $14 \%$ decrease of extreme high maximum temperatures was detected. There were no significant periods with more occurrences of extreme high maximum temperatures (Birjand; Fig. 2a).

In Birjand, the greatest cooling occurred in mid January, February, and early October, measured by the fewer number of days of extreme high maximum temperatures (Birjand; Fig. 2a). In Boujnord, there were 2 statistically significant periods that showed more days of extreme high maximum temperatures and 2 statistically significant periods that showed fewer days of extreme high maximum temperatures in recent years compared to prior years; these were detected during Weeks 6-10 (02/05-03/11), Weeks 40-41 (10/01-10/14), Weeks 27-29 (07/02-07/22), and Weeks 47-48 (11/19-12/02), respectively. The maximum $\chi^{2}$ of 16 occurred during Week $8(02 / 19-$ $02 / 25$ ), with a CT of $\geq 25^{\circ} \mathrm{C}$. The greatest $\%$ change in climate occurred during Week $6(02 / 05-02 / 11)$, when a $16 \%$ increase of extreme high maximum temperatures was detected.

In Boujnord, the greatest warming occurred between February and early March as indicated by the higher number of days of extreme high maximum temperatures, and the greatest cooling occurred between July and late November, as indicated by the lower number of days of extreme high maximum temperatures (Boujnord; Fig. 2c).

In Mashhad, 2 significant periods were detected: during Weeks 31-35 (07/30-09/02) and Weeks 51-52 (12/17-12/30), which showed a higher number of days of extreme high maximum temperatures, and one significant period was detected that showed a lower number of days of extreme high maximum temperatures: Weeks 47-48 (11/19-12/02).

The maximum $\chi^{2}$ of 14 occurred during Week 34 $(08 / 20-08 / 26)$, with a $\mathrm{CT}$ of $\geq 40^{\circ} \mathrm{C}$. The greatest percentage change in climate occurred during Week 47 
(11/19-11/25), when a $12 \%$ decrease of extreme high minimum temperatures was detected. The longest period of significant warming in Mashhad in terms of the increase in the number of days of extreme high maximum temperatures occurred in August.

In Sabzevar, the excess of any occurrence of extreme high maximum temperatures was statistically significant during 2 short periods: Weeks 3-4 (01/1501/28) and Weeks 50-52 (12/10-12/30) (Table 3). There was one significant period with fewer numbers of occurrences of extreme high maximum temperatures, which occurred during Weeks 47-48 (11/1912/2).

The maximum $\chi^{2}$ of 17 occurred during Week 52 $(12 / 24-12 / 30)$, with a CT of $\geq 20^{\circ} \mathrm{C}$. The greatest percentage change in climate occurred during Week 3 , when a $16 \%$ increase of extreme maximum temperatures was detected. For extreme high minimum temperature there were 11 weeks that showed at least $0.5 \mathrm{wk}$ of warming, 3 weeks that showed 1 whole week of climate warming, and there were 3 weeks that showed at least $0.5 \mathrm{wk}$ of climate cooling.

The greatest warming in Sabzevar, in terms of the increase in the number of days of extreme high maximum temperatures, mostly occurred during January and late December.

In Torbat Heydarieh, there were fewer days of extreme high maximum temperatures in recent years compared to prior years, and these days were statistically significant during all months except late March and late December (Table 3). There were 2 statistically significant periods that had fewer days of extreme high maximum temperatures. These days were detected during Weeks $2-12(01 / 08-03 / 25)$ and 14-49 (04/02-12/09). The maximum $\chi^{2}$ of 48 was obtained during Week 24 (06/11-06/17), with a CT of $\geq 40^{\circ} \mathrm{C}$. The percentage change during this week was a decrease of $25 \%$ (Torbat Heydarieh; Fig. 2j).

The occurrence of extreme high minimum temperatures during 2 significant periods (01/08-03/25, $04 / 02-12 / 09$ ) was less frequent on average during the recent period compared to the prior period by 49 and $50 \%$, respectively. Based on the sums of all $52 \mathrm{wk}$ of extreme days, we determined that the recent years averaged $49 \%$ fewer extreme high daily maximum temperatures than the prior years. There were no significant periods with more occurrences of extreme high maximum temperatures. In Torbat Heydarieh, the greatest cooling occurred from January to late March and April to early December, as indicated by the lower number of days of extreme high maximum temperatures (Torbat Heydarieh; Fig. 2i).

\section{DISCUSSION AND CONCLUSIONS}

Climate change is considered one of the main environmental concerns of the present age. Increased variation and changes in mean temperature and precipitation are expected to dominate future changes in climate and to affect crop productivity. In the present study, an iterative $\chi^{2}$ method was used to detect changes in extreme daily minimum and maximum temperatures in 5 different regions of Iran between a $15 \mathrm{yr}$ recent and $30 \mathrm{yr}$ (prior) period. The results of this study showed that the number of days with extreme minimum temperatures during the recent period were less frequent compared to the prior period in all 5 regions, especially in Mashhad and Sabzevar. Mashahd and Sabzevar in recent years averaged 44 and $57 \%$ fewer days of extreme low temperatures than in prior years. In both these regions, warming has occurred during most of the year except in spring. These results agree with the increase in minimum temperatures observed by different studies in Iran. Ebrahimi et al. (2006) found that there was an increasing trend in minimum temperature over a $25 \mathrm{yr}$ recent compared to a $25 \mathrm{yr}$ prior period in Mashhad, especially in summer. Decreasing trends in extreme temperature indices such as FD (number of days with a minimum temperature $<0^{\circ} \mathrm{C}$ ) and ID (number of days with a maximum temperature $<0^{\circ} \mathrm{C}$ ) were reported in Tehran, Iran (Mohammadi \& Taghavi 2005). Possible causes of recent warming were discussed in Kousari et al. (2010); their experiments were carried out by using the Kendall $\tau$ test and reported an upward trend in minimum air temperature during all months for 26 synoptic stations during a 55 yr period in central and eastern Iran. Kousari et al. (2010) concluded that increasing trend of minimum temperature could be the result of increases in the amount of greenhouse gases and the reflection of received thermal energies from land during the night.

The number of days with extreme maximum temperatures increased during 2 short periods in Boujnord, Mashahd, and Sabzevar, and decreased during recent years compared to prior years in Birjand and Torbat Heydarieh. The period from late May to June is the peak cooling period in Torbat Heydarieh. Kousari \& Asadi Zarch (2010) showed a negative trend of maximum temperature in Birjand and Torbat Heydarieh and was significant in Torbat Heydarieh. Torbat Heydarieh and Birjand are located at higher altitudes than the other regions studied here. As noted by Caprio et al. (2009), the levels of significance obtained from the iterative $\chi^{2}$ method may not 
be reliable due to the multiple testing problem. Thus the iterative $\chi^{2}$ analysis described is of an exploratory nature, and further research is needed to obtain more precise estimates of statistical significance.

Acknowledgements. The authors gratefully acknowledge Dr. H. A. Quamme from Pacific Agri-Food Research Centre and Dr. B. Bates from the editorial group of Climate Research for their editorial help and guidance.

\section{LITERATURE CITED}

Bannayan M, Sanjani S, Alizadeh A, Lotfabadi S (2010) Association between climate indices, aridity index, and rain fed crop yield in northeast of Iran. Field Crops Res 118:105-114

Bannayan M, Sadeghi Lotfabadi S, Sanjani S, Mohammadian A, Aghaalikhani M (2011) Effects of precipitation and temperature on cereal yield variability in northeast of Iran. Int J Biometeorol 55:387-401

Barnet J (2010) Dangerous climate change in the Pacific Islands: food production and food security. Reg Environ Change 11:229-237

Caprio JM (1966) A statistical procedure for determining the association between weather and non-measurement biological data. Agric Meteorol 3:55-72

Caprio JM, Quamme HA (1999) Weather conditions associated with apple production in the Okanagan Valley of British Columbia. Can J Plant Sci 79:129-137

> Caprio JM, Quamme HA (2002) Weather conditions associated with grape production in the Okanagan Valley of British Columbia and potential impact of climate change. Can J Plant Sci 82:755-763

Caprio JM, Quamme HA (2006) Influence of weather on apricot, peach and sweet cherry production in the Okanagan Valley of British Columbia. Can J Plant Sci 86: 259-267

Caprio JM, Williams JS 1973. Impact of rainfall on the Great Plain of Montana. Research Report 48, Montana Agricultural Experiment Station. Final report, Bureau of Reclamation Contract No. 14-06-D-7171

Caprio JM, Fritts HC, Holmes RL, Meko DM, Hemming D (2003) A $\chi^{2}$ test for the association and timing of tree ring-daily weather relationships: a new technique for dendroclimatology. Tree Ring Res 59:47-61

Caprio JM, Quamme HA, Redmond KT (2009) A statistical procedure to determine recent climate change of extreme daily meteorological data as applied at two locations in Northwestern North America. Clim Change 92:65-81

Ghahraman B (2006) Time trend in the mean annual temperature of Iran. Turk J Agric For 30:439-448

Ghorbani MH, Soltani A (2003) Climatic change in Gorgan during past 40 years. J Agricult Sci Nat Res 4:3-13

IPCC (2007) Climate Change 2007: the physical science

Editorial responsibility: Bryson Bates,

Wembley, Western Australia, Australia basis. Summary for policymakers. Contribution of Working Group I to the Fourth Assessment Report of the Intergovernmental Panel on Climate Change. Cambridge University Press, Cambridge

> Kousari MR, Asadi Zarch MA (2010) Minimum, maximum, and mean annual temperatures, relative humidity, and precipitation trends in arid and semi-arid regions of Iran. Arab J Geosci 4:907-914

> Kousari MR, Ekhtesasi MR, Tazeh M, Saremi Naeini MA, Asadi Zarch MA (2010) An investigation of the Iranian climatic changes by considering the precipitation, temperature, and relative humidity parameters. Theor Appl Climatol 103:321-325

- Kutcher HR, Warland JS, Brandt SA (2010) Temperature and precipitation effects on canola yield in Saskatchewan, Canada. Agric For Meteorol 150:161-165

> Laux P, Jäckel G, Tingem RM, Kunstmann H (2010) Impact of climate change on agricultural productivity under rainfed conditions in Cameroon - a method to improve attainable crop yields by planting date adaptations. Agric For Meteorol 150:1258-1271

- Lindner M, Maroschek M, Netherer S, Kremer A and others (2010) Climate change impacts, adaptive capacity, and vulnerability of European forest ecosystems. For Ecol Manage 259:698-709

McKeown AW, Warland J, McDonald MR (2006) Long-term climate and weather patterns in relation to crop yield: a mini review. Can J Bot 84:1031-1036

Mohammadi H, Taghavi F (2005) Trend of extreme temperature and precipitation indices in Tehran, Iran. Geogr Res 53:151-172 (in Persian)

- Parry M, Arnell N, McMichael T, Nicholls R and others (2001) Millions at risk: defining critical climate change threats and targets. Glob Environ Change 11:181-183

> Porter JR, Semenov MA (2005) Crop responses to climatic variation. Philos Trans R Soc Lond B Biol Sci 360: 2021-2035

Rahimzadeh F, Asgari A (2004) The study of different rates of increase minimum and maximum temperature and decrease range of mean temperature in Iran. Georgan Res 19:155-171 (in Persian)

Reidsma P, Ewert F, Lansink AO, Leemans R (2010) Adaptation to climate change and climate variability in European agriculture: the importance of farm level responses. Eur J Agron 32:91-102

Sissoko K, Keulen HV, Verhagen J, Tekken V, Battaglini A, (2010) Agriculture, livelihoods and climate change in the West African Sahel. Reg Environ Change 11(Suppl1): $119-125$

> Southworth J, Randolph JC, Habeck M, Doering OC, Pfeifer RA, Rao DG, Johnston JJ (2000) Consequences of future climate change and changing climate variability on maize yields in the Midwestern United States. Agric Ecosyst Environ 82:139-158

> Tao F, Yokozawa M, Xu Y, Hayashi Y, Zhang Z (2006) Climate changes and trends in phenology and yields of field crops in China, 1981-2000. Agric For Meteorol 138:82-92

Submitted: January 21, 2011; Accepted: July 8, 2011

Proofs received from author(s): November 8, 2011 